JPASDEV

Journal of Public Administration

and Sociology of Development

Vol. 1, No.1, Juli 2020

\title{
Implementasi Program Pemberantasan Peredaran Gelap Narkotika Melalui Jalur Perbatasan Negara Republik Indonesia di Kalimantan Barat
}

\author{
Bhayu Kuncoro ${ }^{1}$ \\ 1. Badan Narkotika Nasional Provinsi Kalimantan Barat \\ Korespondesi Penulis Utama: bhayukuncoro23@gmail.com
}

\begin{abstract}
This research entitled The Implentation of the Narcotics Dark Circulation Eradication Program Through the Republic of Indonesia's Border Line in West Kalimantan analyzed based on the theory put forward by Merilee S. Grindle. This research is a type of descriptive research with a qualitative approach. The type of data in this study is primary data obtained from interviews with informants and secondary data obtained from various official documents related to research.

The implementation of the Narcotics Dark Circulatioan Eradication Prgoram through the Republic of Indonesia's Border Line in West Kalimantan has not been able to run optimally due to several factors, namely: 1. The esistence of interests that influence the parties affected by the program, 2. The strategy of the disadvantaged actors especially those involved in narcotics illicit traffincking, 3. Limited resources, 4. Top-down decision making locations.

Based on these problems, the author can make suggestions, namely: 1. There needs to be a support program in the form of a border surveillance program, 2. Increasing the capacity of program implementors both in quality and quantity, 3. Focusing on eradication programs and other support programs in border areas.
\end{abstract}

Key words : The Implementation Policy, Narcotics Eradication. 


\section{PENDAHULUAN}

Permasalahan peredaran gelap narkotika di Indonesia saat ini bagaikan jamur di musim penghujan. Hal tersebut ditandai dengan beberapa kejadian pengungkapan penyelundupan narkotika melalui jalur laut di bulan Februari 2018. Terhitung ada 2 (dua) kapal laut berbendera asing yang telah resmi dinyatakan berusaha menyelundupkan lebih dari 2,6 ton narkotika jenis sabu (Ninis Chairunnisa, 2018). Pengungkapan penyelundupan ini dilaksanakan atas kerjasama antara Badan Narkotika Nasional, Kepolisian Republik Indonesia, Tentara Republik Indonesia, Kementerian Kelautan dan Perikanan serta Direktorat Jenderal Bea dan Cukai Kementerian Keuangan Republik Indonesia. Dari pengungkapan penyelundupan tersebut didapatkan informasi, saat ini Indonesia menjadi negara sasaran yang menggiurkan dalam penyelundupan dan peredaran narkotika.

Menurut Kepala Bagian Hubungan Masyarakat Badan Narkotika Nasional, Komisaris Besar Polisi Sulistiandriatmoko, sebagaimana diberitakan dalam MetroTVnews.com (Anonim, 2017), Indonesia dipilih menjadi sasaran penyelundupan karena 3 (tiga) faktor. Faktor-faktor tersebut antara lain : pertama, permintaan terhadap narkotika illegal yang sangat besar, kedua, kondisi geografis Indonesia sebagaian besar perairan yang sangat memungkinkan dijadikan jalur penyelundupan narkotika dari luar negeri, pengawasan yang kurang ketat dari penegak hukum diwilayah perbatasan, banyaknya pelabuhan-pelabuhan tikus yang dijadikan pintu masuk narkotika. Terakhir, penegakan hukum terhadap bandar dan jaringan narkoba kurang konsisten. Ketiga hal tersebutlah yang menjadikan Indonesia sebagai negara yang sangat menarik untuk penenyelundupan dan peredaran gelap narkotika.

Guna menangani permasalahan tersebut, Badan Narkotika Nasional Provinsi Kalimantan Barat menetapkan langkah-langkah strategis yang bertujuan menekan laju angka prevalensi penyalahguna narkotika. Langkahlangkah strategis tersebut tertuang dalam Program Pencegahan dan Pemberantasan Penyalahgunaan dan Peredaran Gelap Narkotika (P4GN). Program ini memiliki 2 (dua) pendekatan, yakni dengan menekan kebutuhan penyalahgunaan narkotika (demand reduction) dan menekan peredaran gelap narkotika (supply reduction)(Jurnal Data BNN, 2018).

Pendekatan demand reduction, langkah-langkah preventif ditempuh sebagai upaya untuk membentuk masyarakat yang mempunyai ketahanan dan kekebalan terhadap Narkotika. Kegiatan yang dilakukan dalam hal menekan angka prevalensi penyalahgunaan Narkoba menyasar kaum muda (anak-anak, remaja, pelajar, dan mahasiswa) yang merupakan target pasar jaringan sindikat Narkoba. Pendekatan supply reduction BNNP melakukan penindakan terhadap segala bentuk kejahatan Narkotika. 
Gambar 1.1. Kerangka emikiran

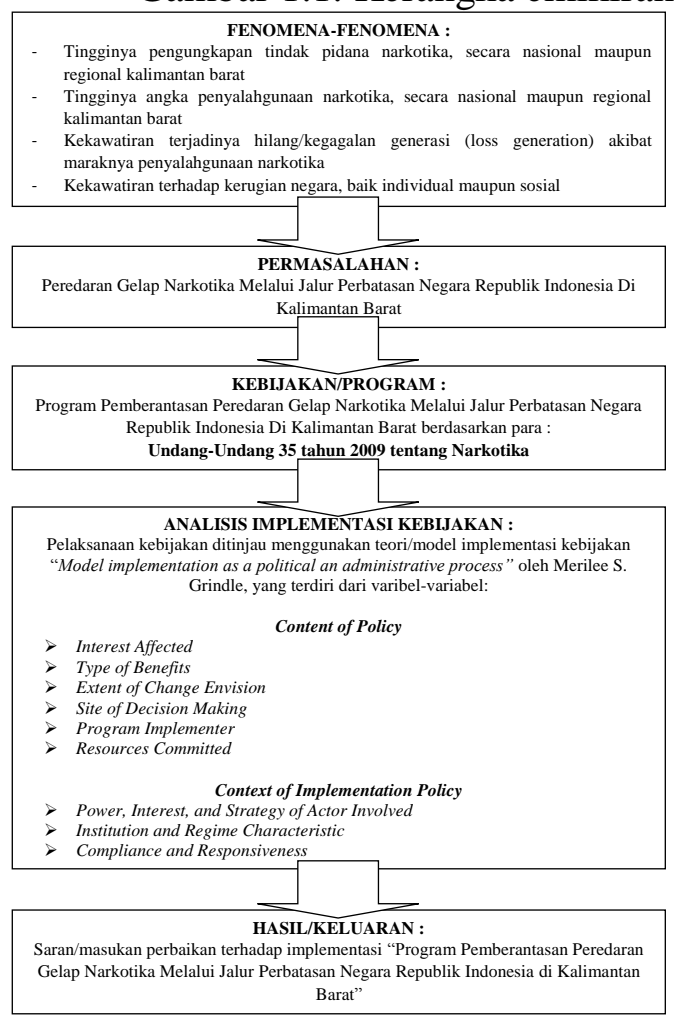

\section{METODE PENELITIAN}

Penelitian ini merupakan sebuah penelitian deskriptif dengan pendekatan kualitatif. Bogdan dan Taylor dalam Moloeng (Moloeng, 2007:4) mendefinisikan penelitian kualitatif sebagai prosedur penelitian yang menghasilkan data deskriptif berupa katakata tertulis atau lisan dari orang-orang dan perilaku yang diamati dari fenomena yang terjadi. Lebih lanjut Moleong (Moloeng, 2007:11) mengemukakan bahwa penelitian deskriptif menekankan pada data berupa kata-kata, gambar, dan bukan angka-angka yang disebabkan oleh adanya penerapan metode kualitatif. Selain itu, semua yang dikumpulkan berkemungkinan menjadi kunci terhadap apa yang sudah diteliti. Pengambilan sampel atau sumber data pada penelitian ini dilakukan secara puposive dan untuk ukuran sampel tersebut ditentukan secara snowball, taknik pengumpulan dengan triangulasi (gabungan), analisa data bersifat kualitatif dan hasil penelitian menekankan makna generalisasi.

Lokasi yang diambil dalam penelitian ini ditentukan dengan sengaja (purposive), yang dilakukan di Kantor Pengawasan dan Pelayanan Bea dan Cukai Tipe Madya Pabean C Entikong dan di kantor BNN Provinsi Kalimantan Barat. Dengan

Pelaksanaan penelitian tentang implementasi pemberantasan peredaran gelap narkotika melalui perbatasan negara Republik Indonesia di Kalimantan Barat ini direncanakan pada bulan Januari sampai dengan Juli 2018.

Obyek dari penelitian ini adalah implementasi pemberantasan peredaran gelap narkotika melalui perbatasan negara Republik Indonesia di Kalimantan Barat yang dilaksanakan oleh implementor dalam hal ini BNNP Kalimantan Barat dan instansi yang terkait dalam pemberantasan peredaran gelap narkotika melalui jalur perbatasan negara.

\section{HASIL DAN PEMBAHASAN}

Untuk melihat keberhasilan implementasi kebijakan publik tidak hanya dengan melihat keberhasilan dari kebijakan itu saja, namun juga melihat pada proses pelaksanaan kebijakan tersebut. Kemampuan suatu kebijakan ditentukan oleh implementabilitas kebijakan itu sendiri. Secara garis besar Marilee S. Grindle mengungkapkan 
implementabilitas suatu kebijakan terdiri dari 2 (dua) variabel besar, yakni variabel isi kebijakan (content of policy) dan variabel lingkungan implementasi kebijakan (context of implementation). Dengan kata lain dari sisi proses implementasi kebijakan dipengaruhi kedua variable besar tersebut. Kedua varibel besar tersebut dibagi menjadi 9 (sembilan) variabel yang terdiri dari :

\subsection{Isi Kebijakan (Content Of Policy)}

\section{a. Kepentingan mempengaruhi}

yang

"Dimana ada kebijakan, maka disitu terdapat kekuatan politik, kepentingan, dan aktor politik yang "bekerja" dan membentuk interseksi, atau bahkan terkadang persinggungan yang berujung pada konflik." (Jurnal Politik Volume 3 Nomor 1 Tahun 2017).

\section{Program}

pemberantasan

peredaran gelap narkotika sebagaimana tertuang dalam Undang-Undang Nomor 35 Tahun 2009 tentang Narkotika, tidak luput dari kepentingan yang mempengaruhi ataupun dipengaruhi. Secara garis besar kepentingan yang mempengaruhi program tersebut berasal dari masyarakat secara umum, pelaksana program (dalam hal ini Badan Narkotika Nasional dan Kepolisian Republik Indonesia) serta Lembaga Swadaya Masyarakat yang peduli terhadap permasalahan narkotika.

Disamping adanya kepentingan yang mempengaruhi, adapula kepentingan yang dipengaruhi dari lahirnya program ini. Kepentingan yang dipengaruhi oleh program ini adalah kepentingan oknum masyarakat ataupun bahkan aparat yang terlibat dalam tindak pidana narkotika.

\section{b. Derajat perubahan}

Untuk mendalami faktor derajat perubahan yang diharapkan, peneliti melakukan wawancara kepada masyarakat. Dalam hal ini peneliti mengambil narasumber dari masyarakat yang peduli terhadap permasalahan narkotika. Peneliti melakukan wawancara terhadap 2 (dua) orang duta anti narkotika Kalimantan Barat. Dari wawancara tersebut didapatkan fakta bahwa perubahan yang diharapkan dari pelaksanaan program pemberantasan peredaran gelap narkoba adalah Kalimantan Barat lebih maju, sehat dan bebas dari penyalahgunaan dan peredaran gelap narkotika. Kondisi saat ini, berdasarkan pada pemaparan narasumber hal tersebut belum tercapai karena program pemberantasan dirasakan belum optimal. Pemberantasan peredaran gelap narkotika dirasa belum memberikan efek jera kepada para tersangka, sehingga peredaran gelap narkotika masih belum bisa ditekan dengan maksimal.

\section{c. Tipe manfaat}

Tipe manfaat suatu kebijakan dapat dibagi menjadi 2 (dua) kategori yakni manfaat kolektif dan manfaat yang dapat dibagikan (divisible). Menurut Grindle kebijakan yang memiliki tipe manfaat kolektif akan lebih mudah diimplementasikan daripada kebijakan yang memiliki tipe manfaat diviside. Hal ini disebabkan kebijakan dengan tipe 
manfaat kolektif mendatangkan lebih sedikit konflik atau perbedaan pendapat.

Thus, programs delivering collective goods such as the provision of light and water in urban slum neighborhoods may be readily implemented in the Third World because the compliance of groups or localities affected will tend to be forthcoming with a minimal amount of conflict or dissent. Programs with divisible benefits such as housing, in contrast, may exacerbate conflict and competition among those seeking to benefit from them and may be more difiicult to execute as intended. (Grindle, 1980 : 8 - 9)

Menilik tipe manfaat yang terkandung dalam undang-undang narkotika sangat jelas terlihat bahwa kebijakan ini memiliki tipe manfaat kolektif. Tercermin dari tujuan kebijakan yang menyebutkan penerima manfaat kebijakan ini adalah rakyat/masyarakat Indonesia secara keseluruhan. Manfaat yang diterima oleh penerima manfaat adalah peningkatan derajat kesehatan dan kesejahteraan. Berdasarkan petikan dari buku Grindle diatas, seharusnya program pemberantasan akan mudah diimplementasikan karena tipe manfaat yang bersifat kolektif dan penerima manfaat telah termuat dengan jelas dalam isi kebijakan.

Untuk mendalami faktor tipe manfaat yang diterima masyarakat, peneliti melakukan wawancara kepada masyarakat. Dalam hal ini peneliti mengambil narasumber dari masyarakat yang peduli terhadap permasalahan narkotika. Peneliti melakukan wawancara terhadap 2 (dua) orang duta anti narkotika Kalimantan Barat. Dari wawancara tersebut didapatkan fakta bahwa tipe manfaat yang diterima merupakan manfaat secara kolektif. Manfaat pelaksanaan program pemberantasan peredaran gelap narkotika yang langsung dirasakan oleh masyarakat adalah terciptanya rasa aman dan berkurangnya keresahan terhadap tindak pidana narkotika.

\section{d. Letak pengambilan keputusan}

Berdasarkan hasil studi dokumen, wawancara dan observasi pada penelitian ini, peneliti menemukan beberapa temuan antara lain mengenai lokasi pengambilan keputusan. Program pemberantasan peredaran gelap narkotika adalah merupakan kebijakan nasional yang diampu oleh Badan Narkotika Nasional. Badan Narkotika Nasional bertanggung jawab langsung kepada Presiden Republik Indonesia. Dengan kata lain, pengambil keputusan utama dalam kebijakan ini adalah Badan Narkotika Nasional.

Badan Narkotika Nasional selaku pengambil keputusan utama berperan sentral terhadap pelaksanaan program pemberantasan peredaran gelap narkotika. Peran sentral Badan Narkotika Nasional dapat diartikan sebagai kewenangan untuk menentukan arah sasaran strategis dari program. Seluruh pelaksanaan kebijakan ditingkat kewilayahan harus mengacu kepada kebijakan utama tersebut.

Menurut penulis, seharusnya sebuah kebijakan selain mengacu kepada standar/aturan nasional juga harus bisa 
menjawab kebutuhan wilayahnya. Maksudnya disini adalah kebijakan pusat menjadi dasar kebijakan utama serta patokan (role model) dalam hal kebijakan teknis, namun daerah juga diberikan ruang untuk menentukan program apa saja yang akan dilaksanakan dengan mengacu kepada data dan fakta yang ada didaerahnya.

Lebih lanjut daerah akan memformulasikan sebuah langkah kebijakan apa yang akan diambil dan pastinya tiap daerah akan berbeda-beda. Seperti jika dibandingkan Provinsi yang memiliki tingkat penyalahgunaan yang tinggi tapi minim akses terhadap jalur masuk narkotika dari luar negeri dengan Provinsi yang tingkat penyalahgunaan narkotikanya rendah namun memiliki akses (entry point) serta jalur masuk narkotika yang banyak.

Provinsi yang rawan terhadap penyalahgunaan narkotika seharusnya mendapatkan porsi yang lebih besar pada program rehabilitasi narkotika dan pencegahan terhadap penyalahgunaan narkotika, seddangkan provinsi yang memiliki jalur masuk narkotika dari luar negeri seharusnya lebih difokuskan kepada pengawasan perbatasan, khususnya pada barang masuk. Saat membahas mengenai penyalahgunaan narkotika dengan mengacu kepada angka prevalensi akan didapatkan jumlah penyalahguna yang menjadi dasar pengambilan keputusan memberikan porsi lebih pada program tertentu. Seperti halnya jika mengacu kepada pengungkapan tindak pidana narkotika, khususnya darimana narkotika itu berasal, maka hal tersebut juga bisa menjadi dasar acuan dalam pengambilan kebijakan dimana harus menerapkan pengawasan terhadap jalur-jalur masuk narkotika tersebut. Jika dilihat dari beberapa kasus ungkapan BNN Provinsi Kalimantan Barat yang barang buktinya hampir semua berasal luar negeri, seharusnya BNN Provinsi Kalimantan Barat diberikan program pengawasan perbatasan tersebut.

\section{e. Pelaksana program/kebijakan}

Dalam Undang-undang 35 Tahun 2009 tentang Narkotika, disebutkan beberapa instansi pemerintah selaku pelaksana (implementor). Beberapa instansi ditunjuk dengan peran dan kewenangannya sesuai dengan tugas dan fungsinya masing-masing.

Secara umum Undang-undang tersebut telah membagi tugas kepada setiap instansi. Disini Kementerian Kesehatan menjadi satu-satunya regulator yang menentukan narkotika menjadi legal atau illegal. Jika narkotika diproduksi, didistribusikan dan digunakan tanpa mengikuti ketentuan Kementerian Kesehatan maka hal itu menjadi illegal atau disebut juga penyalahgunaan dan peredaran gelap narkotika. Sedangkan BNN dan Kepolisian berperan sebagai pengawas serta penindakan terhadap penyalahgunaan dan peredaran gelap narkotika.

Kembali jika berbicara mengenai pemberantasan peredaran gelap narkotika, maka disini perlu berbicara peran yang dimiliki oleh BNN dan Kepolisian. Tugas pokok BNN dan 
Kepolisian yaitu fungsi keamanan dan ketertiban melekat kepada peran tersebut.

\subsection{Sumber daya yang mendukung Lingkungan Implementasi \\ Kebijakan Implementation)

(Context of

a. Kekuasaan, Kepentingan dan Strategi Aktor yang Terlibat

b. Karakteristik Lembaga dan Rezim yang Berkuasa

c. Tingkat Kepatuhan dan Respon Pelaksana Program/Kebijakan

\section{SIMPULAN DAN REKOMENDASI}

Dari hasil penelitian ini ditemukan beberapa hal terkait implementasi program pemberantasan peredaran gelap narkotika melalui jalur perbatasan Negara Republik Indonesia, hal-hal tersebut adalah sebagai berikut :

Dilihat dari kelompok variabel isi kebijakan (Content of Policy) beberapa temuan dijabarkan sebagai berikut :

\subsection{Simpulan}

Dalam isi kebijakan UndangUndang 35 Tahun 2009 telah disebut secara terang mengenai kepentingan yang dipengaruhi atau mempengaruhi. Kepentingan tersebut dimuat dalam tujuan Undang-Undang yakni seluruhnya demi kesejahteraan dan kesehatan masyarakat Indonesia. Kedua yakni kepentingan BNN secara institusional, BNN dalam Undang-Undang ini disebut secara terang sebagai instansi/Lembaga Pemerintah Non Kementerian (LPNK) yang bertugas menangani permasalahan narkotika. a. Derajat perubahan yang diinginkan termuat dalam Undang-Undang 35 Tahun 2009 tersebut. Derajat perubahan yang diharapkan dalam kebijakan tersebut adalah meningkatnya kesejahteraan dan kesehatan masyarakat Indonesia melalui pemberantasan dan penyalahgunaan penyalahgunaan dan peredaran gelap narkotika. Selain itu derajat perubahan juga dapat dilihat dalam ukuran-ukuran keberhasilan yang termuat dalam Rencana Strategis BNN sebagai terjemahan dari UndangUndang 35 Tahun 2009.

b. Tipe manfaat yang terkandung dalam Undang-Undang 35 Tahun 2009 sangat jelas terlihat bahwa kebijakan ini memiliki tipe manfaat kolektif. Tercermin dari tujuan kebijakan yang menyebutkan penerima manfaat kebijakan ini adalah rakyat/masyarakat Indonesia secara keseluruhan. Manfaat yang diterima oleh penerima manfaat adalah peningkatan derajat kesehatan dan kesejahteraan. Oleh karena itu seharusnya program pemberantasan akan lebih mudah diimplementasikan karena tipe manfaat yang bersifat kolektif dan penerima manfaat telah termuat dengan jelas dalam isi kebijakan.

c. Letak pengambilan keputusan kebijakan ini berada di level pemerintah pusat. Setiap program dirancang oleh BNN RI dalam mendukung kebijakan tersebut. Instansi vertikal ditingkat wilayah, seperti BNN Provinsi Kalimantan 
Barat berperan sebagai pengambil kebijakan teknis dengan mengacu kepada kebijakan yang ditentukan oleh BNN RI. Pada variabel ini muncul sebuah temuan yang menarik, yakni ada program dari kebijakan ini yang menurut peneliti lebih tepat diberikan kepada BNN Provinsi Kalimantan Barat sebagai program andalan, namun tidak didelegasikan oleh BNN RI. Program tersebut adalah Interdiksi / pengawasan perbatasan negara. Dilihat dari kondisi geografis Kalimantan Barat yang memiliki perbatasan dengan luar negeri sepanjang lebih kurang 944 kilometer yang menurut data ungkapan kasus narkotika merupakan kawasan rawan masuk narkotika dari luar negeri, maka sangat tepat program tersebut didelegasikan ke BNN Provinsi Kalimantan Barat.

d. Pelaksana kebijakan disebut dengan jelas dalam Undang-Undang 35 Tahun 2009. Beberapa peran dibagikan kepada beberapa Instansi Pemerintah setingkat Kementerian. Salah satu peran sentral dalam kebijakan ini adalah BNN. BNN merupakan instansi yang diberikan kewenangan melaksanakan program Pencegahan dan Pemberantasan Penyalahgunaan dan Peredaran Gelap Narkotika (P4GN). Bersama dengan Kepolisian Republik Indonesia, BNN diberikan peran yang cukup besar dalam penanganan permasalahan narkotika. Dalam kebijakan ini juga disebutkan organisasi BNN hingga tingkat Provinsi dan Kabupaten/Kota. e. Sumberdaya yang mendukung disebutkan dalam beberapa pasal pada Undang-Undang 35 Tahun 2009. Beberapa hal terkait sumberdaya yang disebutkan dalam kebijakan tersebut antara lain aset, kewenangan, dan fasilitas (sarana dan prasarana). Untuk lebih jelas mengenai hal terkait sumberdaya diterbitkan Perpres 23 Tahun 2010 tentang Badan Narkotika Nasional. Dalam Perpres ini dituangkan lebih rinci mengenai sumberdaya yang mendukung kebijakan program pemberatansan peredaran gelap narkotika.

Dilihat dari kelompok variabel lingkungan implementasi kebijakan (Context of Implementation) beberapa temuan dijabarkan sebagai berikut :

a. Pelaksanaan program pemberantasan peredaran gelap narkotika melalui jalur perbatasan Negara Republik Indonesia tidak luput dari kepentingan aktor dan strateginya. Beberapa aktor yang mempengaruhi pelaksanaan kebijakan ini adalah para pelaku peredaran gelap narkotika, khususnya para bandar besar. Bandar besar tidak segan-segan merekrut orang-orang baru untuk masuk kedalam sindikatnya, bahkan menggunakan oknum aparat. Beberapa kasus membuktikan keterlibatan aparat penegak hukum. Tindakan tegas sampai dengan pemecatan tidak menjadi efek jera bagi oknum-oknum tersebut. Iming-iming materi lebih menggiurkan bagi mereka. Strategi yang digunakan oleh bandar besar antara lain dengan menggunakan 
strategi "sel terputus". Masing-masing orang dalam jaringan tidak mengenal satu sama lain. Kalaupun kenal biasanya hanya 1 (satu) level dibawah atau diatasnya saja. Hal ini yang menyulitkan petugas dalam pengungkapan jaringan sindikat narkotika. Disamping itu jaringan biasanya menggunakan warga lokal perbatasan untuk menyelundupkan narkotika melalui jalur-jalur tikus / hutan didaerah perbatasan. Pertimbangannya adalah warga perbatasan sangat mengenal area dan kondisi geografis perbatasan.

b. Karakteristik pelaksana dalam hal ini BNN Provinsi Kalimantan Barat telah sesuai dengan tugas pemberantasan peredaran gelap narkotika. Hal ini tercermin dari struktur organisasi dan anggota organisasi sudah dibekali dengan kemampuan penyelidikan, penyidikan, dan penindakan peredaran gerap narkotika. Rezim pemerintahan memberikan dukungan dalam bentuk kebijakan teknis berupa Instruksi Presiden. Pemerintah serius dalam penanganan permasalahan narkotika. Bahkan pada tahun 2015 Presiden menyebutkan "Indonesia Darurat Narkoba" dan pada tahun 2018 Presiden menetapkan Instruksi Presiden tentang rencana aksi nasional P4GN yang memerintahkan seluruh komponen masyarakat tanpa terkecuali melaksanakan aksi melawan narkotika sesuai dengan tugas dan fungsinya.

c. Dalam pelaksanaan program pemberantasan peredaran gelap narkotika melalui jalur perbatasan negara Republik Indonesia, BNN Provinsi Kalimantan Barat selaku pelaksana teknis tunduk dan patuh kepada aturan perundangan yang ada, dalam hal ini Undang-Undang Nomor 35 Tahun 2009 tentang Narkotika. Kepatuhan dilaksanakan untuk menghindari kemungkinan dipraperadilan-kan oleh tersangka. Seorang penyidik tidak hanya harus patuh pada peraturan perundangan, namun juga tunduk.

\subsection{Rekomendasi.}

Berdasarkan hal tersebut diatas, maka dapat disimpulkan keberhasilan pelaksanaan program pemberantasan peredaran gelap narkotika melalui jalur perbatasan Negara Republik Indonesia didukung oleh kebijakan yang memiliki implementabilitas yang tinggi. Pada variabel isi kebijakan hampir tidak menjadi kendala walaupun ada beberapa catatan mengenai kewenagan menentukan program oleh BNN Provinsi Kalimantan Barat.

\section{Referensi}

\section{Buku-buku:}

Arikunto, S. (1993). Prosedur Penelitian-Suatu Pendekatan Praktek. Jakarta: PT. Aneka Cipta.

Bungin, B. (2007). Penelitian Kualitatif. Komunikasi, Ekonomi, Kebijakan Publik, dan Ilmu Sosial Lainnya. Edisi 1, Cetakan ke-1 bulan April. Jakarta: Prenada Media Group.

Cangara, H. (2002). Pengantar Ilmu Komunikasi. Jakarta: PT. Raja Grafindo Persada.

Damsar. (2010). Pengantar Sosiologi 
Politik. Jakarta: Kencana.

Effendi, O.,U. (1999). Ilmu Komunikasi Teori dan Praktek. Bandung: Remaja Rosdakarya.

Hadi, S. (2004). Metodologi Research. Yogyakarta: Andi.

Kurniawati, H. D. (2018). Gagasan Pemilihan Umum Kepala Daerah Asimetris Menuju Tata Kelola Pemerintahan Daerah Demokratis, Akuntabel dan Berkelanjutan. Yogyakarta: LIPI.

Miles, M.B dan A. Michael H. (1992). Analisis Data Kualitatif: Buku Sumber tentang Metode-metode Baru. Alih Bahasa Tjetjep Rohendi Rohidi. Jakarta: UI-Press.

Moleong J. L. (2012). Metodologi Penelitian Kualitatif. Edisi Revisi. Cetakan ke Dua Puluh Delapan. Bandung: Remaja Rosdakarya.

Mukoram, Z. (2016). Komunikasi Politik. Bandung: Pustaka Setia.

Nawawi, I. (2009). Public Policy: Analisis, Srategi Advokasi Teori dan Praktek. Surabaya: Penerbit PMN.

Nawawi, H. (1991). Metode Penelitian Bidang Sosial. Yogyakarta: Gadjah Mada University Press.

Nazir, M. (2011). Metode Penelitian. Jakarta: Ghalia Indonesia.

Subejo dan Supriyanto. (2004). Harmonisasi Pemberdayaan Masyarakat Pedesaan dengan Pembangunan Berkelanjutan. Buletin Ekstensia, Pusat Penyuluhan. Pertanian Deptan RI Vol 19 Tahun XI/2004.

Sukmadinata, N. S. (2011). Metode Penelitian Pendidikan. Bandung: Remaja Rosdakarya.

Rudy. (2009). Hukum Pemerintahan Daerah Perspektif

Konstitusionalisme Indonesia. Bandar Lampung: Indepth
Publishing.

Tabroni, R. (2014). Marketing Politik Media dan Pencitraan di Era Multipartai. Yogyakarta: Graha Ilmu.

Wahab, S.,A. (2000). Analisis Kebijaksanaan: Dari Formulasi ke Implementasi Kebijaksanaan Negara. Jakarta. Bumi Aksara.

Wardhani, A. M dan Haryadi, Em. (2004). Pemberdayaan Masyarakat dalam Penanggulangan Kemiskinan. Oleh: Gugus Tugas II Pemberdayaan Masyarakat. Jakarta: TKP3 KPK, Kementerian Koordinator Bidang Kesejahteraan Rakyat.

Wijaya, E. J. (2004). Memahami Sosisologi. Bandung: Armico.

\section{Publikasi dan Internet:}

Gileko, Petrus., Agung Suprojo dan Asih Widi Lestari. ( 2017). Strategi Komisi Pemilihan Umum dalam Upaya Meningkatkan Partisipasi Politik Masyarakat Pada Pemilihan Umum Kepala Daerah. Program Studi Ilmu Administrasi Negara. Fisip, Universitas Tribhuana Tunggadewi, Malang. https://144163-ID-strategi-komisipemilihan-umum-upaya. pdf-adobe acrobat reader DC. Diakses di Pontianak, Tanggal 28 Agustus 2019.

Kuncoro, Wahyu Muhammad. (2018). Media Sosial, Trust dan Partisipasi Politik Pada Pemula. Program Doktor, Fakultas Psikologi, Universitas Gadjah Mada, Yogyakarta. Jurnal Visi Komunikasi Volume 13, No. 01, Mei 2014: 50-68. https://142747ID-media-sosial-trust-partisipasipolitik-di-k. pdf-adobe acrobat reader DC. Diakses di Pontianak, 
Tanggal 15 Juli 2019.

Morisson. (2014). Media Sosial dan

Partisipasi Sosial di Kalangan

Generasi Muda. Program Doktoral,

Universitas Sains, Malaysia.

https://193759-ID-media-sosial-

dan-partisipasi-sosial. pdf-adobe acrobat reader DC. Diakses di Pontianak, Tanggal 10 Agustus 2019.

Sugino., A.B Tangdililing., Gusti S. ( 2015). Faktor Internal Pelaksanaan Partisipasi Politik Masyarakat Perbatasan dalam Pemilu Presiden dan Wakil Presiden Pada Tahun 2014 di Kecamatan Entikong Kabupaten Sanggau. Program Studi Ilmu Politik, Magister Ilmu Sosial, Universitas Tanjungpura, Pontianak. Jurnal Tesis PMISUntan-Fisip-2015. http:// 190706ID-faktor-internal-pelaksanaanpartisipasi. pdf-adobe acrobat reader DC. Diakses di Pontianak, Tanggal 27 Juni 2019.

\section{Dokumentasi dan Peraturan}

Perundang-undangan:

Undang-undang Republik Indonesia Nomor 7 Tahun 2017 tentang Pemilihan Umum.

Undang-undang Republik Indonesia Nomor 15 Tahun 2011 tentang Penyelenggaraan Pemilu.

Peraturan Komisi Pemilihan Umum Republik Indonesia Nomor 8 Tahun 2017 tentang Sosialisasi, Pendidikan Pemilih dan Partisipasi Masyarakat dalam Pemilihan Gubernur dan Wakil Gubernur, Bupati dan Wakil Bupati, dan/atau Walikota dan Wakil Walikota.

Peraturan Komisi Pemilihan Umum Republik Indonesia Nomor 10 Tahun 2018 tentang Sosialisasi, Pendidikan Pemilih dan Partisipasi
Masyarakat dalam Penyelenggaraan Pemilihan Umum. 